\title{
中心窩における光幕光量に関する研究 I
}

摘出した牛の眼球による測定結果からの検討

$\begin{array}{ccccc}\text { 正会員 } & \text { 中 } & \text { 根 } & \text { 芳 } & \text { 一* } \\ \text { 正会員 } & \text { 土 } & \text { 井 } & & \text { 正** }\end{array}$

\section{1. 目的}

筆者は, 従来から明視照明設計のための基礎データを

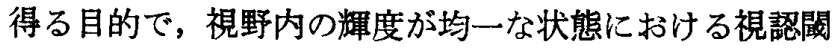
值としての背景輝度と視対象物の大きさ及び対比との関 係を示す等視力曲線や, 輝度の不均一な背景が見え方に 及ぼす影響，印刷された文字の見え方（活字の大きさ・ 字画数・文章等とランドルト氏環視標との関係及び読み 易さ評価）などについて実験的研究を行い, 報告して来 $た^{1)}$ 。

視野内の輝度が不均一な場合, 筆者の研究結果でも, また蒲山福の結果でも， 視対象の背景輝度より周囲の輝 度がやや低い方が見易いということが明らかになってい る。しかしこの現象は眼の順応輝度といら面からでは充 分説明できない。なせなら視野内の輝度が不均一な場合 の順応輝度を視野内の輝度が均一な状態で同じ視対象が 視認できたときの輝度でもって規定できるとし，また順 応の程度によって網膜の感光度が変わることから網膜の 感光度にあった背景輝度のとき最も見易いと考えるなら ば, 周辺部がやや暗い場合の網膜の感光度は視対象の背 景輝度より低くなるから，視野内の輝度が均一な場合上 り見難くなるはずである。そこで先の現象を説明するに は，視対象物の見かけの対比を考える必要がある。視対 象物の見かけの対比は, 視対象物の中心窩での映像に, 視野内にある物体から中心窩に射入する迷走光（中心窝 部分の網膜上に正しく映像を結ばずに射入して来る光の 総称。以下眼球迷走光と呼ぶ）がかぶって低下するとい え，眼球迷走光の把握が重要になって来る。また，眼の 順応が中心窩及びその付近の網膜上に射入する光の量に よって決をるとするならば，やはり眼球迷走光量を知る ことが重要である。更に，一般に不能グレアといわれる 見易さをそこなうグレアは，空・光源などの高輝度面に よって起る視対象一の光幕光や視対象の表皮反射光によ る視対象物の対比の低下が原因である。この高輝度面に よ，て起る視対象への光幕光がすなわち眼球迷走光であ る。このように，見易い照明設計を行ならためには，視 対象の対比の低下や眼の順応に影響寸る眼球迷走光につ

* 大阪市立大学 講師

** 大阪市立大学: 大学院

(昭和 53 年 1 月 23 日本稿受理・封㖮期限昭和 54 年 1 月末日)
いて解明する必要があ る。

そこで人間の眼球の 代りに，牛の眼球を使 用して眼球迷走光を测 定したので報告する。

牛の眼球光学系の屈
表-1 眼球光学系屈折率一臨表

\begin{tabular}{cc|c|c}
\hline & & 人 & 生 \\
\hline 屏 & 水 & 1.3354 & 1.3340 \\
角 & 膜 & 1.3760 & 1.3760 \\
硝子 体 & 1.3354 & 1.3340 \\
水晶 & 体 & 1.5470 & 1.5610 \\
\hline
\end{tabular}

(日眼全春より)
折率は 表一1に示すように比較的人間の眼球光学系の屈 折率と類似している。また，眼球組織による 可視光の 吸収について, 中泉 ${ }^{3)}$, Roggenbau \& Wetthauer"), Ludvigh \& McCarshy $^{51}$, Goldmann ${ }^{6)}$, 山地 ${ }^{7)}$, 飯沼 ${ }^{8)}$, 山地・山本帛等による人, 牛, 家兔の眼球を用いた測定 結果等がある。これらの研究によれば, 動物の種類によ る眼球光学系の透過率について顕著な差は, 白色の家鬼 において，角膜の柴外線吸収に認められているだけであ る。可視部に於ける房水・硝子体の透過率は約 95\% で 波長による透過率の差も殆んど見られず, 角膜, 水晶体 の透過率は紫外部から $450 \mathrm{~mm}$ まで顕著に増加するが， それ以後 $85 \%$ 前後で波長による差異も殆んどない。以 上の結果, 光の経路長の差を考虑しても, 人と牛の眼球 光学系に注相当な類似性が認められている。

故に，牛の眼球を用いて測定した中心䆟における光幕 光量の研究は, 人間の眼球内にお污る光幕光量, さらに は視対象物の視認や Veiling glare（光幕によるまぶし さ）の研究に大いに寄与するものであると考える。

網膜の表面の部分は, 機能的あるいは便宜上でいくつ かの区域に分けて，それぞれ名前がつけられている。中 心简 (fovea) とは網膜の中央付近のくぼんだ所を指して いるが，そのくぼみの一番底部は平らになっておりここ こを中心小简 (foveola) と呼んでいる。この中心小窩の 直径は視角 $1^{\circ} \sim 1.4^{\circ}$ の範囲である。桿状体が存在しな いと言われるのはこの部分で，視力の最も高い部分とな る。故に本論文で中心窩と述べている部分は，正しくは 中心小窝を指す。

\section{2. 実験方法}

大阪市食肉市場で提供を受けた牛の眼球を $0^{\circ} \mathrm{C}$ の生 理的食塩水中に入れて運搬 - 保存し, 測定直前に眼科用 のトレパンを用いて 直径 $4 \mathrm{~mm}$ の孔を網膜中心窩に相 当する部分にあけて硝子体を露出させ；その孔にフィル 
ターで視感度補正をしたシリコン光電池，(SBC）をセ ットして, 網膜中心窩に於ける照度 (以下中心窩照度と 呼ぶ）を測定した。中心窩の中央に SBC をセット寸る 時, $\mathrm{SBC}$ 受光素子を僅かに前後 $( \pm 0.3 \mathrm{~mm}$ 以内であ った）させて，光源の結像面に位置するようにした。死 後の眼球では, 虹彩内の平滑筋一の刺激が無くなるため 瞳孔が全開した状態になり，また毛様体筋が緩むため， 毛様小帯が緊張し，水晶体は引張られて薄くなり，正規 の網膜位置では無限遠にピントが合う状態になる。しか し，網膜位置が $1 \mathrm{~mm}$ ずれると 3 ディオプトリーの変 化に相当するというから，無限遠にピントがあった摘出 眼球でも, 本実験で標準光源として用いた視角 $1^{\circ}$ の光 源 (2 m 位置) にピントの合う焦点面は正規の網膜位置 より約 $1 / 6 \mathrm{~mm}$ だけ後にずれた位置といらことになる。 従って本測定では, 受光素子の位置を微調整してピント を合わせているので，結像面で受光していると考える。 更に，この場合の受光面位置は，正規の網膜以置から極 く僅か後方にずれているが，中心窩に扔ける迷走光量に は殆んど影響を与えていないと考えられる。SBC の受 光角は, 人間の眼の視力の高い部分が注視点を含む $1^{\circ}$ の 範囲であるといわれていることから，この角度にあわせ

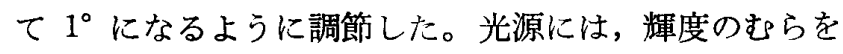
なくすために乳白アクリル板（光搪散板）を入れたスラ イドプロジェクターを使用し，その前面に丸形の孔のあ いた遮光板を置いて光源の大きさを調整し，眼球から見 た光源の大きさが視角 (以下光源視角と呼び $\alpha$ で示す) で $1^{\circ}$ になるようにした。測定装置の光学系の概要を図 -1 に示す。本論文では，中心小窩と水晶体の中心を結 ぶ直線を視軸と考元，その直線を延長した直線を以下視 線と呼ぶ。眼球への入射光と視線のなす角度（以下光源 偏角と呼び $\theta$ で示す）の変更は, 光源を固定したまま, 供試する眼球をターンテーブル上にセットして回転させ ることによって行なった。光源の大きさの変更は, 眼球 から光源までの距離の調整によって行なった。尚，スラ イドプロジェクターを用いた光源では大きな光源が造れ ないため，光源が視線上にある状態（この場合，眼球へ の入射光と視線とがなす角度, 寸なわち光源偏角は $0^{\circ}$ である)については，拡散光によって照明された調光室

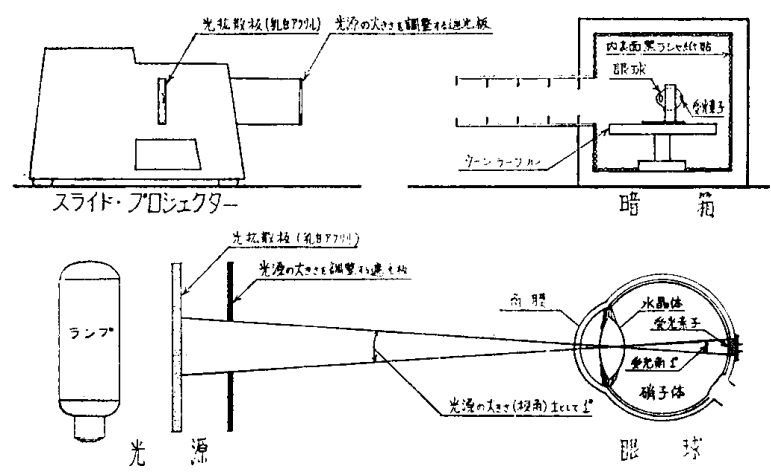

図-1 実験装置及びその光学系の説明図
（論文報告集，Vol. 229，p. 101）参照の内表面を白（ほ ぼ完全拡散面）又は黒（ほぼ完全吸収面）に仕上げ，観 察空の正面，注視点にそれぞれ黒（視角 $1^{\circ} \sim 40^{\circ}$ ）の円 形吸収板, 又は白 (視角 $2^{\circ} \sim 40^{\circ}$ ) の円形反射板を貼付 した条件のもとでも眼球の中心窝照度を測定した。即 ち，白の円形反射板を貼付した場合は，そのままその大 きさの輝度の低い光源とみなせ，また黒の円形吸収板を 貼付した場合は，その測定值を円形吸収板のない時の測 定値から差引けば，黒の円形吸収板と同じ大きさの反射 形光源があったときの中心窩照度が得られる。尚, 本研 究では, 先にも述べた如く, 視線上に在る視対象物の映 像が受光素子上に結像するよ5に，受光素子の位置を極 く僅か前後させて調節している。この受光素子上に視対 象物の映像が結像しているときの視対象物の在る位置を 注視点と呼ぶことにする。本来 “注視点”といえば，人 が或る物を見ようとして眼の焦点を合わせた点を指し， 或る視対象物を見ようとする人間の意志が働いている が，眼球の網膜中心窝に射入する光の量のみを問題にし ている場合, 視細胞, 視神経, 脳の働きは除外されるか ら，注視点を網膜中心窩に結像する物点と考えてよいと いえる。

3. 眼球摘出後の 経過時間が 中心筒照度に及ぼす影響 についての予備測定

光源が 注視点（光源偏角 $0^{\circ}$ ）にあるときの，眼球を

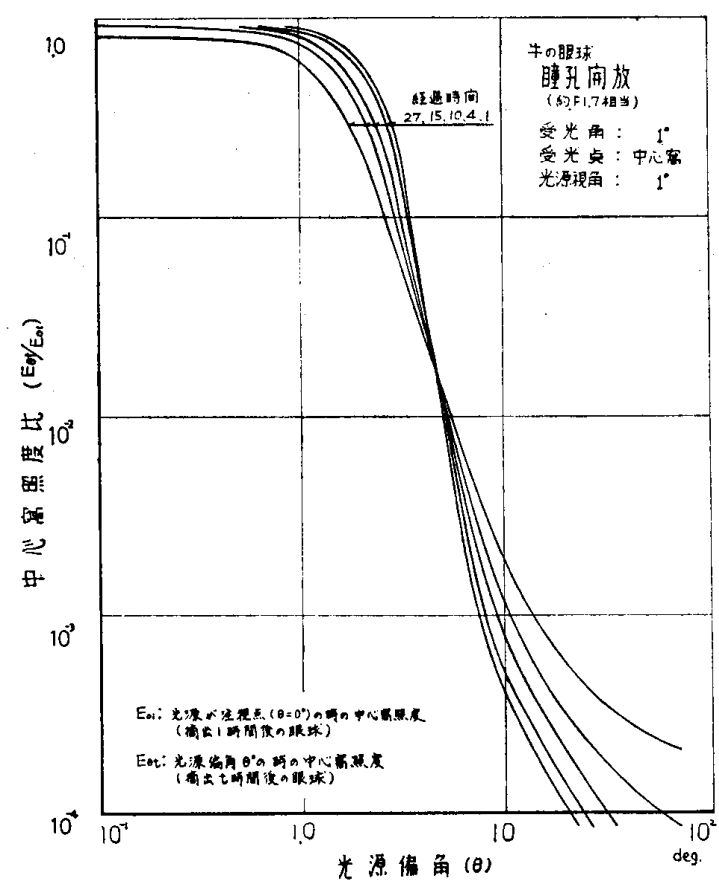

図一2 眼球摘出後の経過時閒が巾心茼照度比 に及ぼす影䋣

表-2 眼球摘出後の経過時間別測定眼球数

\begin{tabular}{|c|c|c|c|c|c|c|c|c|c|c|c|c|c|}
\hline & \multicolumn{12}{|c|}{ 眼球摘 出後の経過時間 } & \multirow{2}{*}{$\begin{array}{l}\text { 合計 } \\
\text { 個数 }\end{array}$} \\
\hline & 1 & 2 & 3 & 4 & 5 & 6 & 7 & 8 & 9 & 10 & 15 & 27 & \\
\hline 測定 & 2 & 29 & 25 & 22 & 20 & 15 & 6 & 6 & 8 & 6 & 3 & 5 & 147 \\
\hline
\end{tabular}


摘出してから 1 時間後の中心窩照度 $\left(E_{01}\right)$ を基準とし $\tau$, 眼球摘出後の経過時間別に光源偏角と中心䆟照度の 関係をまとめると図一2のようになる。また表一2に経 過時間別に測定した眼球の個数を示す。尚, 光源偏角は 主として眼球の水平方向について測定した。中心窩照度 は視線に対して左右ほぼ対称であり，眼球の鉛直方向に ついて測定した数例の結果も，中心窩照度比がやや小さ くなる傾向はあるが，有意差があるとはいえず，個体差 以上の差異ではないことから眼球での迷走光の発生に関 して，光の入射方向は問題にならないといえる。

光源が注視点近くにある場合, 時間経過につれて, 中 心窩照度は減少して行くが，光源が注視点から $5^{\circ}$ 以上 離れている場合の中心窝照度は時間がたつにつれて増大 している。図一3 に光源が注視点にある時の中心窝照度 の時間経過による減衰を, 摘出 1 時間後の眼球の中心窝 照度を基準とした比率で示す。

動物の死亡前後による眼球の光学性能の変化は, 虹彩 や焦点の調節機能が無くなるだけで，その他には特別な 変化はなく，最も賃み易い角膜でも，角膜移植用に保存 液 (1.3\% 食塩水) で1ケ月保存できた例もあり，1 日 以内ならば問題にならないといわれているので, 測定可 能な最短時間の測定値として摘出 1 時間後の中心窩照度 測定値を基準として用いた。

図一3 によると，5 時間以内での変化はほぼ無視でき る程度であり，10 時間で約 4\%，27 時間で約 $20 \%$ の 減少である。また光源偏角が $10^{\circ}$ の場合の眼球迷走光に よる中心窝照度 $\left(\theta>1^{\circ}\right.$ では. 光源の映像は 中心窩に入 らないから， $\theta=10^{\circ}$ の時の中心窩照度は眼球での歪や

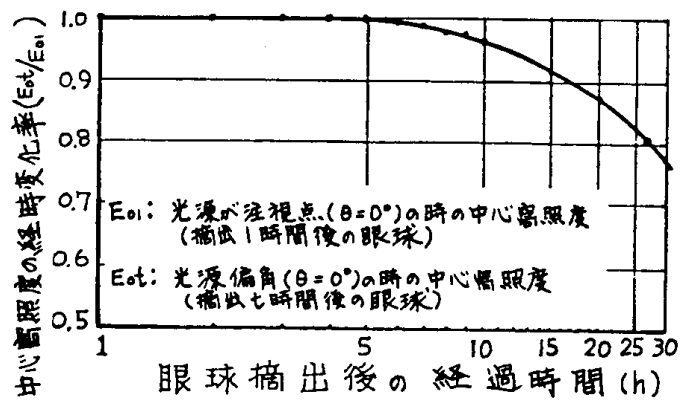

图一3 光源偏角 $0^{\circ}$ のときの中心䆚照度比の時間変化

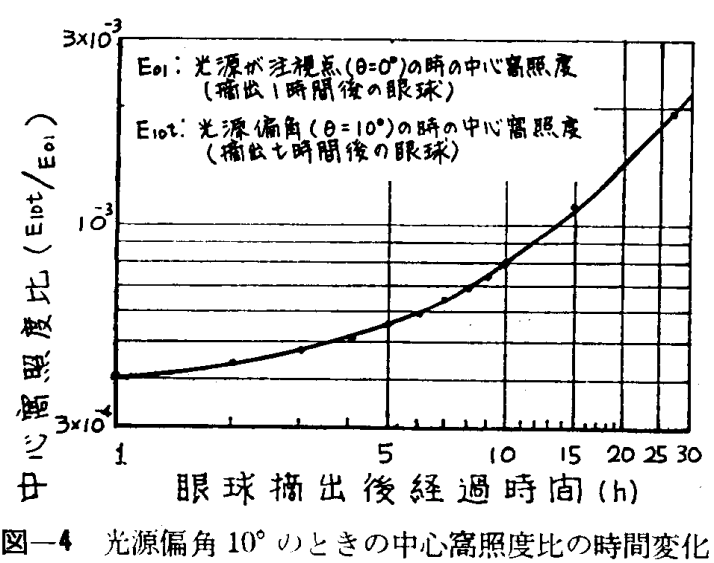

散乱による眼球迷走光のみによる照度である）の摘出 1 時間後の眼球での 光源の映像による中心窩照度 $\left(\theta=0^{\circ}\right.$ での中心䆟照度）に対する比率が眼球摘出後の経過時間 によって変化する状態を図一4に示す。

結局, 時間経過が眼球での迷走光量に及ぼす影響は, 眼球摘出後 10 時間まではそれ程著しくなく，特に 5 時 間以内では無視出来る程度の量であるといえる。

BOYNTON らは，猫の眼を用いて眼球摘出後の経 過時間が眼球迷走光に及ぼす影響について調べ，中心窝 照度は 時間経過と共に 急激に 増加し, 特に光源偏角が $7^{\circ} \sim 8^{\circ}$ の時に最も著しいと述べている ${ }^{10)}$ 。しかし，この BOYNTON らの結果は，筆者の結果と相違している。 筆者の実験では, $0^{\circ} \mathrm{C}$ の生理的食塩水中に保存した牛の 眼球を使用し，時間の経過による中心墖照度への影響を 調べる場合も，それぞれの経過時間保存した新しい眼球 を用いて測定した場合，眼球摘出後 10 時間以内では， 時間経過が中心墖照度に及ぼす著しい影響は認められな かった。この相違の原因は，BOYNTON の測定が 1 眼 だけの実測であり，故に同一の眼球について経時的に行 なわれているため, 網膜に孔をあけてセットした眼球が 時間経過につれて傷んだことにあると考えられる。今回 の測定結果から言えば，保存に注意すれば，眼球摘出後 10 時間以内なら眼球迷走光の測定に支障はなく，デー 夕も充分信頼出来ると考えられる。

故に, 本実験では以後, 眼球摘出後 8 時間以内のもの について測定した結果を用いて検討する。

\section{4. 測定結果}

4.1 光源の偏角之網膜中心窝照度の関係

3 節の結果に基づいて, 眼球摘出後 8 時間以内（平均 経過時間 40 時間）の中心窩照度の測定結果をまとめ て, 光源偏角との関係を示したのが図一5である。尚, 光源の映像が 受光素子に一致する $\theta=0^{\circ}$ の時の中心窩 照度 $\left(E_{0}\right)$ を基準 とし, 光源偏角 $\theta^{\circ}$ での中心窩照度 $(E \theta)$ との比率を中心窩照度比とする。光源の大きさ 受光部の大きさともに $1^{\circ}$ であるから, 光源偏角 $1^{\circ}$ 以内 の範囲では, 光源からの直接光も, 受光素子に入ってい るが， $1^{\circ}$ 以上の範囲では，眼球迷走光のみによるもの である。眼球迷走光の現われ方は, 光源偏角 $10^{\circ}$ 以下と $10^{\circ}$ 以上で異なり, 光源が視線に近づいた場合, 著しく 迷走光が強くなる。測定值のばらつきが比較的小さいこ とから, 眼球の光学的個体差は少ないものと思われる。

4.2 絞り径と中心窩照度の関倸

普通，我々が物を見る場合，明るさに応じて虹彩が開 閉し，入射光量を加減する。しかし，摘出した眼球の虹 彩は開いたままであるので, 虹彩の開閉による眼球迷走 光への影響を調べるために, 虹彩の代わりに眼球の直前 に絞りを設置して測定した。その結果を図一6に示寸。 絞りが絞られて瞳孔径の小さな状態に相当するようにな 


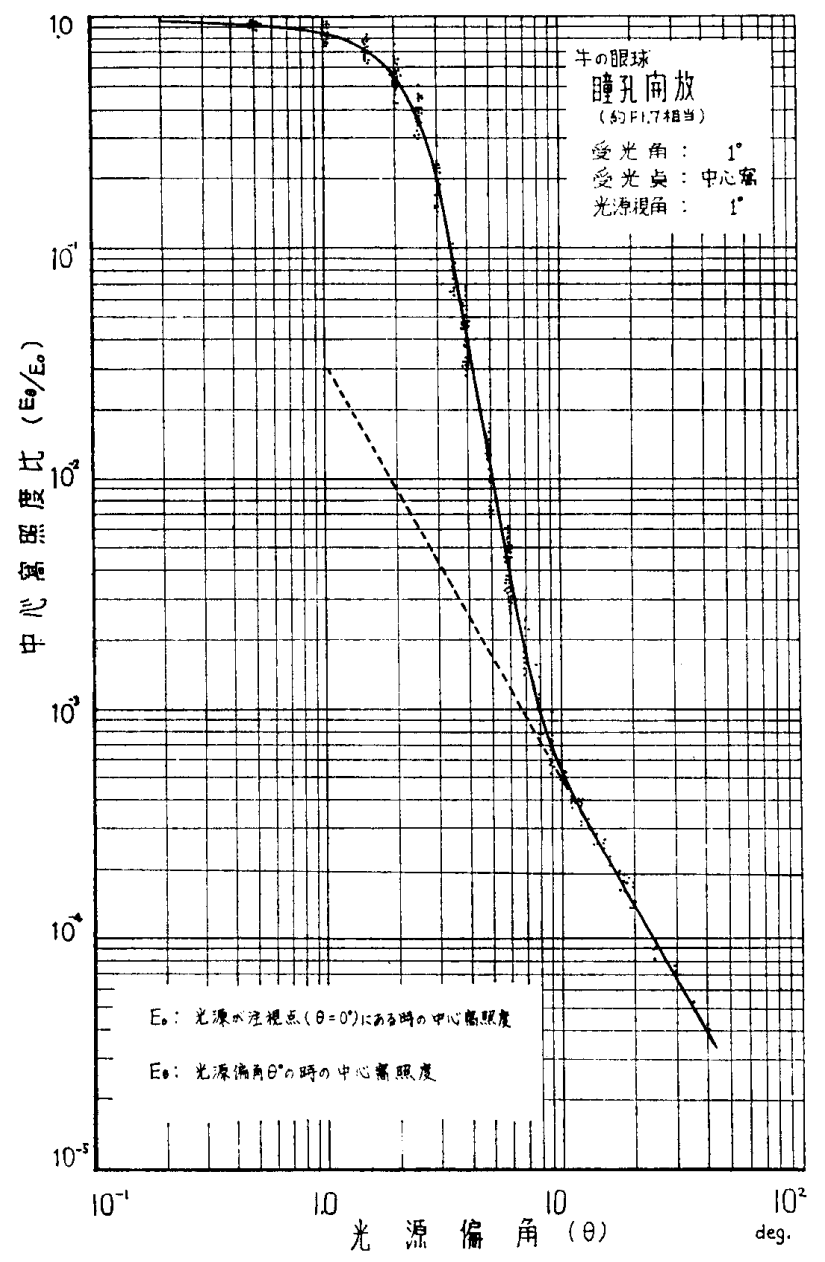

图一5 光源偏角が中心䈑照度に及ぼす影響

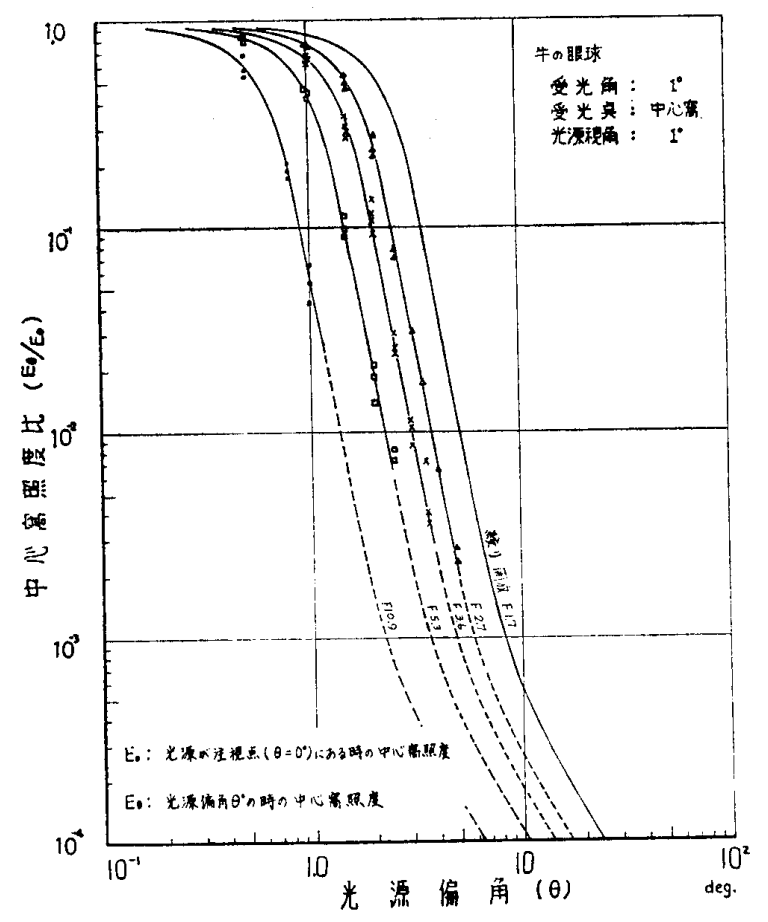

図一6 光源偏角と中心筒照度の関倸に及ぼす 絞り径の影響

った場合，眼球迷走光はだんだん光源が視線の近くにあ る時だけに限られて来ることがわかる。

光源偏角と中心窩照度比の関倸への絞り径の影響は, 絞りが開放状態での結果を, 紋りの径が小さくなるに従
って光源偏角の小さな方へほぼ平行移動したような傾向 となって現われてくる。しかし絞った場合, 眼球へ入っ て来る光の量が少なくなるため, 光源偏角が少し大きく なると受光素子の暗電流の影響を受けて測定不可能にな った。故に図一6に示す点線部分は一応外挿したもので ある。

\section{3 光源の大きさと中心䔰照度の関倸}

光源の大きさが眼球迷走光の強さに及ぼす影響につい て調べるために, 光源と眼球との距離を変化させて光源 の視角上の大きさを変え, 視角 $0.5^{\circ}, 1^{\circ}, 2^{\circ}, 4^{\circ}, 8^{\circ}, の$ 5 種類の光源について各光源偏角での中心䆚照度を測定 し, 検討した。また， $\theta=0^{\circ}$ の状態については, 光源視 角 $1^{\circ}, 2^{\circ}, 4^{\circ}, 6^{\circ}, 8^{\circ}, 10^{\circ}, 20^{\circ}, 40^{\circ}$ の円形反射板(反射 型低輝度光源と考えられる) を用いて測定した。結果を 図一7, 表一3 に示す。光源の大きさが 各光源偏角によ って発生する迷走光の割合に及ぼす影響は, 瞳孔径が変 化した時の影響ほど大きくなく, 比較的少ない。例えば, $\theta=3^{\circ}$ の時, 光源の大きさの影響は, $\alpha=1^{\circ}$ の $E_{\theta} / E_{0}=$ $0.19, \alpha=10^{\circ}$ の $E_{\theta} / E_{0}=0.86$, があるのに対し, 絞り の影響は $F=1.7$ の $E_{\theta} / E_{0}=0.19, \quad F 10.9$ の $E_{\theta} / E_{0}=$ 0.0004 である。しかし, 迷走光の量 (中心窩照度) そ のものへの光源の大きさの影響は 表一3 でもわかる通 り,例えば $\alpha=1^{\circ}$ の $E_{0}=4100 \mathrm{~lx}, \alpha=10^{\circ}$ の $E_{0}=93000$ $1 \mathrm{x}$ とかなり著しい。表一3 は拡散光によって照明され た調光室に於て円形反射板 (反射型円形光源とみなせる) を用いて測定したものである。

この調光室の内壁面全面が 白色仕上げのままの状態 を，牛の眼球を通じて見たとき，中心窩照度は $1650 \mathrm{~lx}$ であった。その照明条件のまま牛の眼球の視線上の壁面 （注視点）に完全吸収に近い反射特性をもった黒ラシャ 紙の円形視標 (円形吸収板, 視角 $1^{\circ} \sim 40^{\circ}$ ) を提示し, 眼球迷走光による中心窩照度を測定した。これは視線を 中心としてそれぞれの視標の範囲を除いた周辺部から中 心窝へ入って来る光量を示している。また，今測定した 中心窩照度を，視野内全面の壁が白色仕上げの時の中心 窝照度 $1650 \mathrm{~lx}$ から差引けば，それぞれの円形吸收板が 占为ていた部分によって起る中心窩照度が得られる。こ の結果を表-3I に示す。

次に調光室内表面を全部黒ラシャ紙で覆い, 注視点に 白色の円形視標 (円形反射板, 視角 $2^{\circ} \sim 40^{\circ}$ ) を順次提 示した状態についても測定を行なった。即ち, 光源偏角 $0^{\circ}$ のときの視角 $2^{\circ} \sim 40^{\circ}$ の大きさの光源による中心窝 照度が求まる。この測定結果を表一3II に示す。

表-3I の黑色の円形視標で測定した結果から求めた 注視点にある光源（大きさは黒色円形視標と同じ）によ る中心䆚照度と 表-3II に示寸白色の円形視標 (光源) が注視点にあるときの中心窩照度を比較すると, 黒色の 円形視標での測定值から計算した中心窝照度の方がやや 


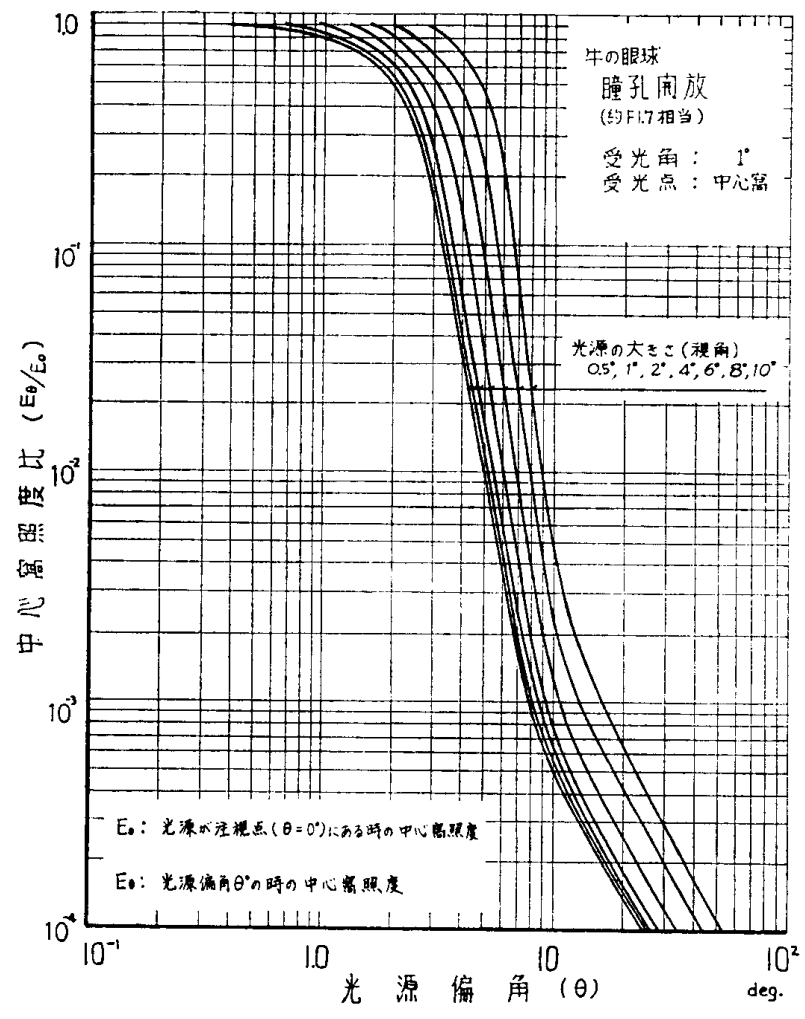

図-7 光源偏角と中心简照度比の関係に及ぼす光源 の大きさの影響

表一3 円形反射型光源による中心営照度の測定結果

\begin{tabular}{|c|c|c|c|c|c|c|}
\hline \multirow{9}{*}{ 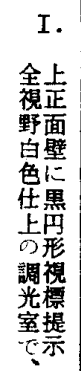 } & & A & B & C & D & $E$ \\
\hline & & lx & $\mathrm{A} / 1650$ & $1.00-B$ & $\begin{array}{l}\mathrm{Cx} \\
11 \text { 万 } 1 \mathrm{l}\end{array}$ & $1 \mathrm{x}$ \\
\hline & 全視野白色仕上 & 1650 & 1.00 & & & \\
\hline & 視線上正面 $1^{\circ}$ 黑視標 & 1590 & 0.964 & 0.036 & 3960 & 4100 \\
\hline & $\Rightarrow 2^{\circ}$ & 1430 & 0.867 & 0.133 & 14630 & 15000 \\
\hline & $4^{\circ}$ & 910 & 0.551 & 0.449 & 49390 & 50000 \\
\hline & $6^{\circ}$ & 460 & 0.279 & 0.721 & 79310 & 80000 \\
\hline & $8^{\circ}$ & 310 & 0.188 & 0.812 & 89320 & 90000 \\
\hline & $\Rightarrow 10^{\circ}$ & 260 & 58 & 0.842 & 92620 & $(93000)$ \\
\hline 視 & $\Rightarrow \quad 20^{\circ}$ & 220 & 0.133 & 0.867 & 95370 & $(96000)$ \\
\hline 線 & $\Rightarrow \quad 40^{\circ}$ & 190 & 0.115 & 0.885 & 97350 & $(98000)$ \\
\hline II. & & A & B & $\mathrm{C}$ & D & $\mathrm{E}$ \\
\hline & & $1 \mathbf{x}$ & 50 & & $\begin{array}{l}\mathrm{B} \times \\
11 \text { 万 } \mathrm{lx}\end{array}$ & $1 \mathbf{x}$ \\
\hline & 全視野黒色仕上 & 0 & 0 & - & & - \\
\hline 上䋈 & 視線上正面 $2^{\circ}$ 白視標 & 230 & 39 & - & 15290 & 15000 \\
\hline 正 & $4^{\circ}$ & 760 & 0.461 & - & 50710 & 50000 \\
\hline & $10^{\circ}$ & 1400 & 0.848 & - & 93280 & $(93000)$ \\
\hline & $20^{\circ}$ & 1440 & 0.873 & - & 96030 & $(96000)$ \\
\hline 脃 & $\Rightarrow \quad 40^{\circ} \quad$ & 1470 & 1 & - & 98010 & $(98000)$ \\
\hline & 全視野白色仕上 & 1650 & 1.000 & - & 110000 & $(110000)$ \\
\hline
\end{tabular}

$\mathrm{A}$ : 調光室内での拡散光照明による実即中心照照度の平均值（受光 角 $1^{\circ}$ )。

B : 全視野均一拡散照明下での中心简照度に対寸る各策件下での中 心䆚照度の此。

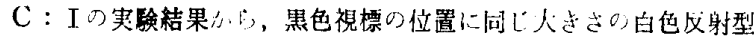

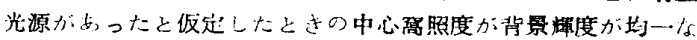
視野での中心照照度に対与万比。

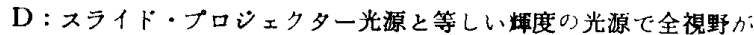

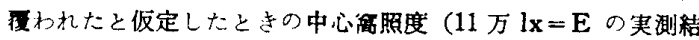
果から外搟）に基ついて反射光源の粘果をスライト・プロシェ クター光源に換算。

考

$\mathrm{E}$ ：反射型視標々同じ視角のスライド・プロシェクター光源（高湈 度光愿）が視線上に志るときの実测中心赛照度平均值（受光角 $1^{\circ}$ )（カッコ内数字）(1外插値。
低くなっている。しかし, 両者の平均值を求め,この平 均值と両者の值とを比較すると，それぞれ $\pm 2.3 \%$ 以 内に納まっており，両者の差は非常に僅かで測定結果の 信頼性は高いと考えられる。

スライド・プロジェクター光源（視角 $1^{\circ} \sim 8^{\circ}$, 光源偏 角 $0^{\circ}$ ) での実測結果に基づいてスライド・プロジェク ター光源が全視野を覆ったと仮定したときの中心墖照度 を外挿する（実測した中心窩照度とその時の光源の大き さとの関係をグラフに描き, 光源視角 $8^{\circ}$ 以上は $1^{\circ} \sim 8^{\circ}$ の結果を延長して外插した）と約 11 万 $\mathrm{lx}$ となる。こ の結果を用いて反射型光源の結果をスライド・プロジェ クター光源での 中心窩照度に換算すると表-3 の D 橍 に示寸值となり，スライド・プロジェクター光源での実 測值に，非常に近い值が得られた。

輝度の低い反射型光源 (円形視標) の結果から換算し ても, 輝度の高いスライド・プロジェクター光源での実 測でも同じ結果が得られたことから，眼球迷走光比は光 源の明るさに関係なく一定であり，本実験での中心窩照 度比（又は眼球迷走光比）と光源偏角との関係があらゆ る輝度の光源に適用寸ることが出来ることを示している といえる。ところで, 眼球迷走光比とは光源偏角 $0^{\circ}$ (光 源の映像面積が受光素子面に一致する）での中心窩照 度を基準にした時の，光源の映像に基づく照度を除い た光源偏角 $\theta^{\circ}$ での眼球迷走光のみによる中心窩照度 の比である。

\section{5. 考察}

\section{1 光源偏角が網膜の中心墖照度に及ぼす影響}

図一5によると，光源偏角約 $10^{\circ}$ を境にして，眼球 迷走光にかなりの相違が認められる。即ち，光源が視 線に近い時と離れた時とで，中心窝照度に影響を与え る眼球迷走光の 発生の 原因が 異なるものと考えられ る。視線近傍で著しく，離れると急激に減衰するよう な迷走光が出来る原因としては，図一8 に示すような 眼球光学系の周辺部 (角膜と水晶体の周辺部, 主とし て角膜周辺と思われる）の歪が考えられる。

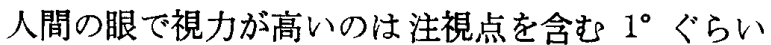
の範囲といわれている。その原因は主として網膜中心 窩には錐状体細胞のみが密に分布しているためと一般 に考えられている。しかし，眼球光学系周辺部の歪も 無視できないといえる。

これらのことは, 図一6に於て眼球值前に絞りを人

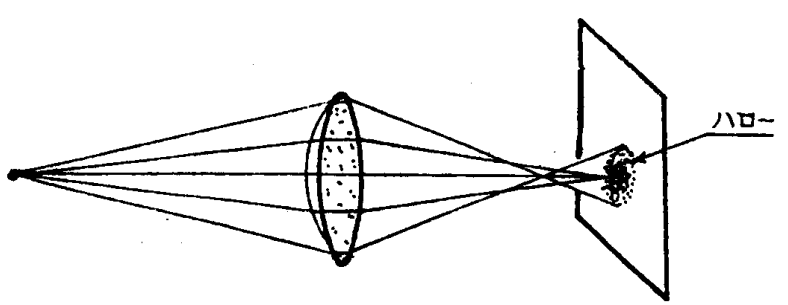

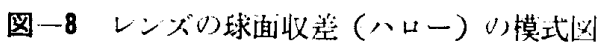


れた場合，眼球周辺部を通る光線がカットされて，著し く眼球迷走光が減少したことでも 説明される。（本実験 の場合, 視野内には 1 個の光源しかなく，その光源にピ ントを合わせてあるから，絞り込まれたことによる被写 界深度が梁くなったことによる影響は考えられない。)

次に視線から光源が離れている場合にみられる眼球迷 走光の 状態を 観察すると, 光源偏角の 変化にともなっ て, 偏角が大きくなる程一定割合で減少することがわか る。このような迷走光が現われる原因としては, 眼球表 面及び眼球内部（水晶体・硝子体, 網膜表面など) での 光の散乱が考えられる。しかし, 網膜表面での反射光の 影響については, 眼球側面の網膜に孔（直径 $4 \mathrm{~mm}$, 視 角にして約 $9^{\circ}$ になる）をあけてその部分に当った光線 を外に逃がしてみても中心窩照度に変化がなかったこと から 無視できる。また, 時間経過の測定をしている時 の, 肉眼での観察で, 角膜の白濁が最も目立つ変化であ ったことを考えあわせると，光源偏角が大きい場合に顕 著になる眼球迷走光の主原因は角膜表面での散乱光と思 わ礼る。尚, 写真撮影用レンズにセンターフォーカスレ ンズを重ねて周辺透過光の焦点を少しずらし，更に透明 ビニールフィルムを重ねて 全面に少し光散乱を起こさ せ, 焦点面で照度を測定した結果, ほぼ牛の眼球での測 定結果に近い状態が得られた。従って上記の眼球迷走光 の原因についての考察の妥当性を確認しているが, これ に関しては，後日改めて報告する。

5.2 校り径が中心窩照度に及ぼす影響

図一6に於いて，虹彩の代りに設けた絞りの径が小さ くなった場合, 眼球迷走光は著しく減少し, 光源偏角の 小さな方へほぼ平行移動したような状態を示している。

この原因は，5.1で説明したように，虹彩が絞られる

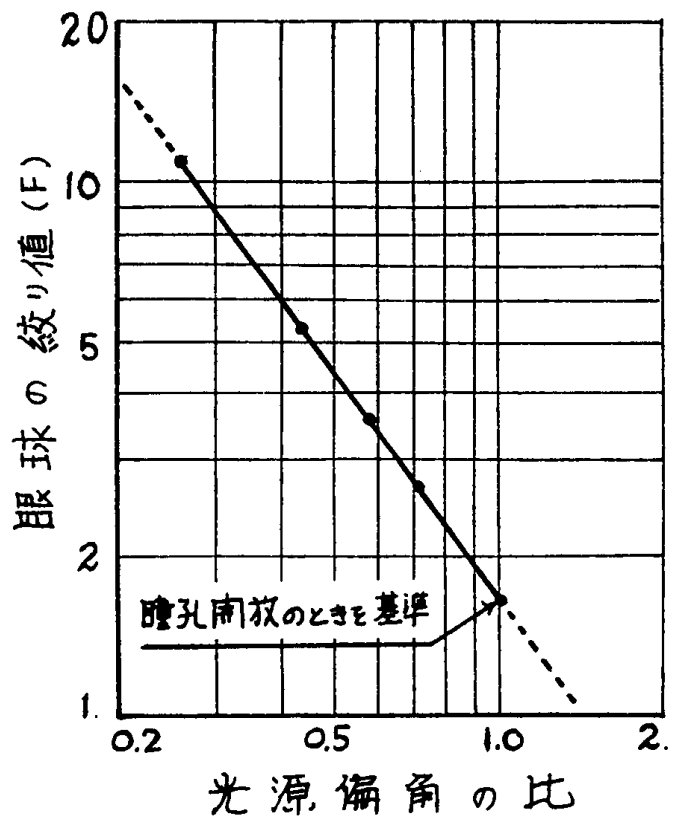

図一9瞳孔開放状態上同じ中心䔰照度が発生与 る光源偏角の比上眼球絞り值の閔保
上眼球周辺の歪の多い所を通った光線が遮断されるため 上考えられる。

瞳孔径が開放状態（人工絞りを設けていない状態）で の光源偏角と中心窝照度比の関倸基準として, 絞りの 径が変ったとき, 開放時の值に等しい中心䆟照度比が現 われる光源偏角と絞り值 ( $F=$ 焦点距離/実効絞り径) の関係を図示したものが図一 9 である。尚, 摘出した牛 の眼の焦点距離は，太陽光を用い一部の供試体について の測定した結果に基づいて平均約 $25 \mathrm{~mm}$ とした。

こ扎らことから, 背景輝度が高くなる程, 視力が傐 くなる原因の 1 つとして，明るいと瞳孔径が小さくな り, 眼球迷走光が減じて視対象物の対比が高くなり, 見 易くなることが指摘出来る。

\section{3 光源の大きさが中心窩照度に及ぼす影響}

光源の大きさが，光源偏角と中心䆟照度比の関倸に 与える影響は 曈孔径の 変化による 影響ほど大きくない が，中心简照度そのものが光源の大きさの変化に伴って 表一3 に示すように著しく変化することから光の量その ものへの影響は決して小さくない。

特に背景となる全視野の輝度が均一な場合の中心䆟照 度と, 注視点 $1^{\circ}$ を除いて周囲をほぼ完全吸收性の黒ラ シャ紙で覆って測定した中心窝照度の比較で, 注視点 $1^{\circ}$ の範囲に基づく中心窩照度は 4\% 程度にすぎず，視野内 の背景の輝度が均一な場合, 中心窩への光幕となってか ぶって来る光の量, すなわち veiling 光量（本論文で定 義した迷走光照度になる）は，全体の $96 \%$ 以上の割合 にのぼることがわかった。これは, 眼球の中心小墖で受 けている視対象物の対比が輝度計で測定した対比と較べ て，非常に低いことを意味している。

大きな光源による中心窩照度は，理論的にはその光源 を小さく分割した各部分によって得られる中心窩照度を 加算したものになる。そこで今回測定した大きさ $2^{\circ}$, $4^{\circ}, 8^{\circ}$ の光源の立体角を, $1^{\circ}$ の光源の立体角を基準にし て分割し，その各部分が視線となす偏角における中心窝 照度比を図一8 から求め, それを加算して得た累積中心 䆟照度比に $\alpha=1^{\circ}, \theta=0^{\circ}$ での実測中心窩照度を掛けて 求めた中心窩照度計算值と, 実測した中心窩照度を比較 した。光源の各光源偏角毎の立体角の算定は, 注視点と 光源の関係を描いた図の上に，同し射影方式で描いた等 立体角網目を重衫て，注視点加ら $1.5^{\circ}, 2.5^{\circ}, 3.5^{\circ} \cdots$ 偏 った点を中心と寸る $1^{\circ}$ 幅の光源の立体角を読み取る力j 法で行なった。

补算の手順を視的 2゚の大きさの光源が視線士（光源 偏角 $0^{\circ}$ ) にある場合を例にして次に少し詳しく説明す る。

視角 $2^{\circ}$ の大きさの光源の立体角は， $1^{\circ}$ の大きさの光 源の 4 倍ある。しかし $2^{\circ}$ の光源の中心部分 $1^{\circ} の$ 範囲以 $1^{\circ}$ ৩大きさの光源偏角 $0^{\circ}$ の值そのものに相当する。次 
に $2^{\circ}$ の光源の中心部 $1^{\circ}$ を除いた周辺部の立体角は $1^{\circ}$ の光源の 立体角の 3 倍となり, 3 ユニットに分割出来 る。そして各ュニットの立体角の中心は視線から $0.79^{\circ}$
偏った位置にある。

以上のことから光源偏角 $0^{\circ}$ に在る $2^{\circ}$ の大きさの光源 による中心䆚照度は, 光源偏角 $0^{\circ}$ の大きさ $1^{\circ}$ の光源 1

表-4 種々の大きさり光源における中心窩照度の実測值と計算值の比較

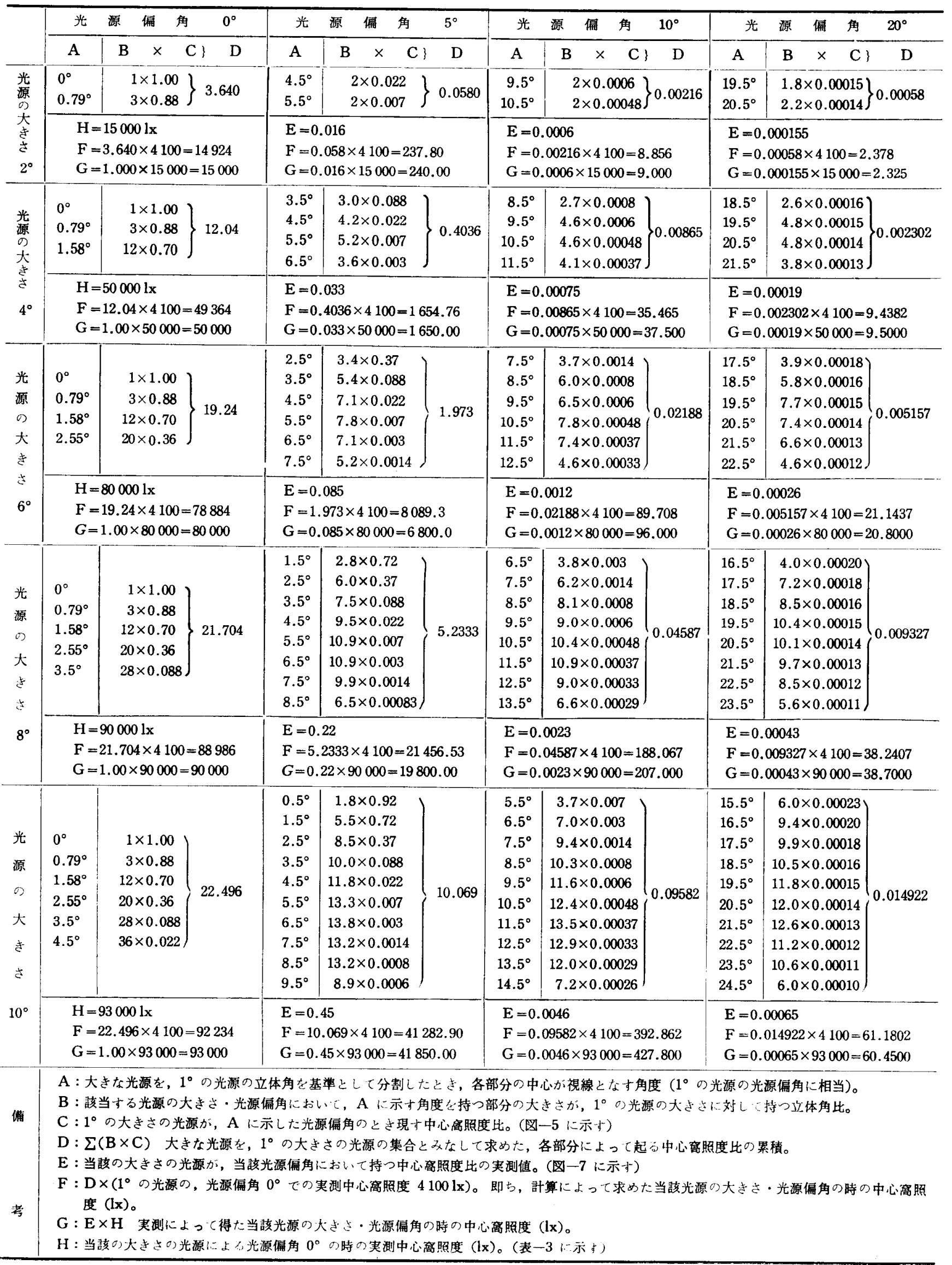


個による中心窩照度と, 光源偏角 $0.79^{\circ}$ の大きさ $1^{\circ}$ の 光源 3 個による中心窩照度の合計として求められる。

$1^{\circ}$ の大きさの光源が 偏角 $0^{\circ}$ のときの中心曧照度比 $\left(E_{\theta} / E_{0}\right)$ は 1.00 であり, 偏角 $0.79^{\circ}$ での $E_{\theta} / E_{0}$ は 0.88 である。よって $1.00+0.88 \times 3=3.64$ が大きさ $2^{\circ}$ の光源 (光源偏角 $0^{\circ}$ ) の, $1^{\circ}$ の光源（光源偏角 $0^{\circ}$ ) の 中心窝照度に対する比となる。

視角 $1^{\circ}$ の光源が注視点 $\left(\theta=0^{\circ}\right)$ に在るときの中心窩 照度の実測值は $4100 \mathrm{~lx}$ であるから，これを 3.64 倍 したのが，視角 $2^{\circ}$ の光源が視線上にあるときの計算に よって求めた中心窝照度ということになる。即ち，3.64 $\times 4100 \mathrm{~lx}=14924 \mathrm{~lx}$ が計算による大きさ $2^{\circ}$ の光源 (光 源偏角 $0^{\circ}$ ) の中心窩照度となり, その実測值 $15000 \mathrm{~lx}$ とほぼ一致することがわかる。

計算結果の一部を 表一 4 に示すがどの光源偏角に於て も両者はよく一致した。また, 光源偏角 $0^{\circ}$ の反射型光 源（大きさ $2^{\circ} \sim 40^{\circ}$ ) について計算した結果でもよく一 致することから, 眼球迷走光の加算が可能であり, 本研 究で得た視角 $1^{\circ}$ の光源での眼球迷走光と光源偏角の関 係を用いて, 空など色々な形の光源による眼球迷走光量 を求められることが確認された。

5.4 中心窝照度比と光源偏角の関係を示実験式 眼球中心窩照度比と光源偏角の関係を表す実験式を導 $<$ と,

$$
\begin{aligned}
& \theta>1^{\circ} \text { のとき } \\
& E_{\theta} / E_{0}=\exp \left\{(-\ln \theta)^{3}-0.25\right\}+0.032 \theta^{-1.8} \cdots(1) \\
& \theta \leqq 1^{\circ} \text { のとき } \quad E_{\theta} / E_{0}=\exp (-0.17 \theta) \cdots \cdots(2)
\end{aligned}
$$

但し, $E_{0}$ : 光源が注視点 $\left(\theta=0^{\circ}\right)$ のときの中心窝照度 (lx)

$E_{\theta}$ : 光源偏角 $0^{\circ}$ のときの中心窝照度 $(\mathrm{lx})$ となる。図一10 に実験式值と実測值を併せて示す。

この測定は光源の大きさ, 受光素子の大きさともに $1^{\circ}$ の状態で行なったので, $\theta \geqq 1^{\circ}$ のときの中心窩照度比 は光源が注視点にあるときの中心窩照度に対する各光源 偏角での眼球迷走光による中心窩照度の比を表わしてい るか゚, $\theta<1^{\circ}$ での中心裔照度比には光源からの直接光 成分も含まれている。この直接光成分については後日改 めて報告する。

尚，(1) 式の右辺第 1 項は眼球光学系の歪による迷走 光を, 第 2 項は眼球表面での散乱光による迷走光を表わ すものであると考えられる。

5.5 眼球迷走光に関する従来の研究と本研究絬果と の比較

沧-11 にBOYNTON, ENOCH \& BUSH, FRY \& ALPERN らの実験結果を示す ${ }^{11)}$ 。BOYNTON らが求 めた中心窝照度比はいずれの光源偏角です, 筆者の結果 より謞くなっている。これは，BOYNTON の使った装 置の光源の大きさが $4.76^{\circ}$, 受光角が約 $4^{\circ}$ といずれも

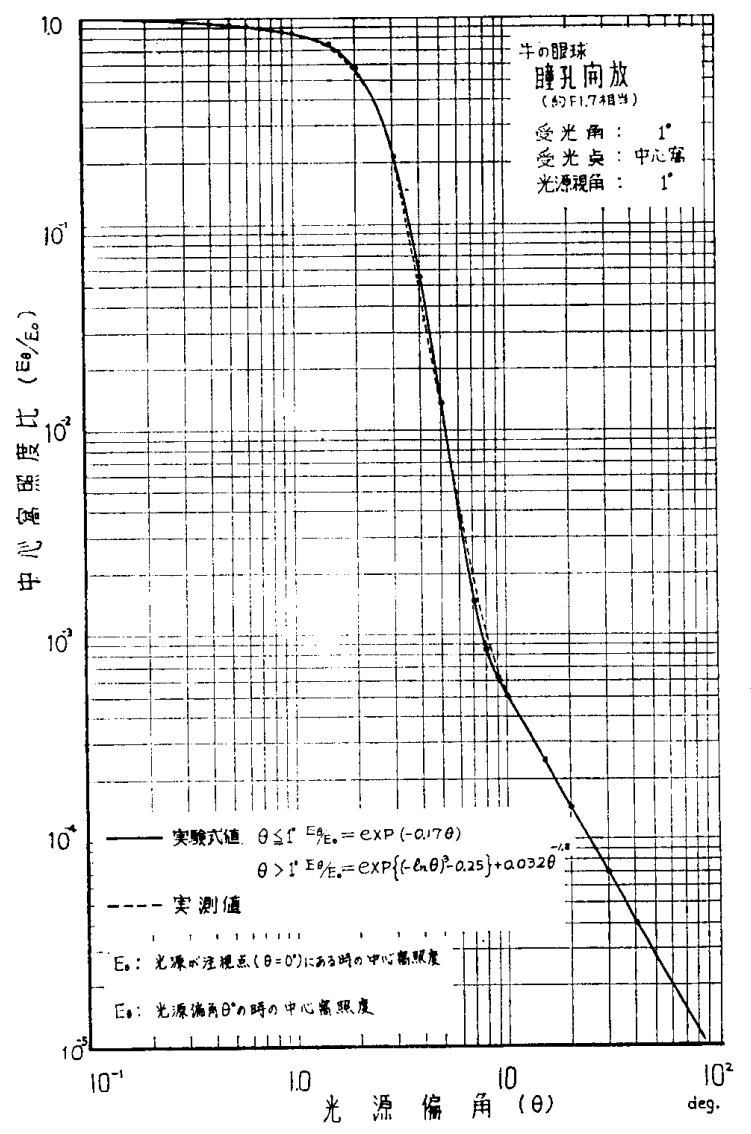

図-10 矢験式値と㬰測結果の比較図

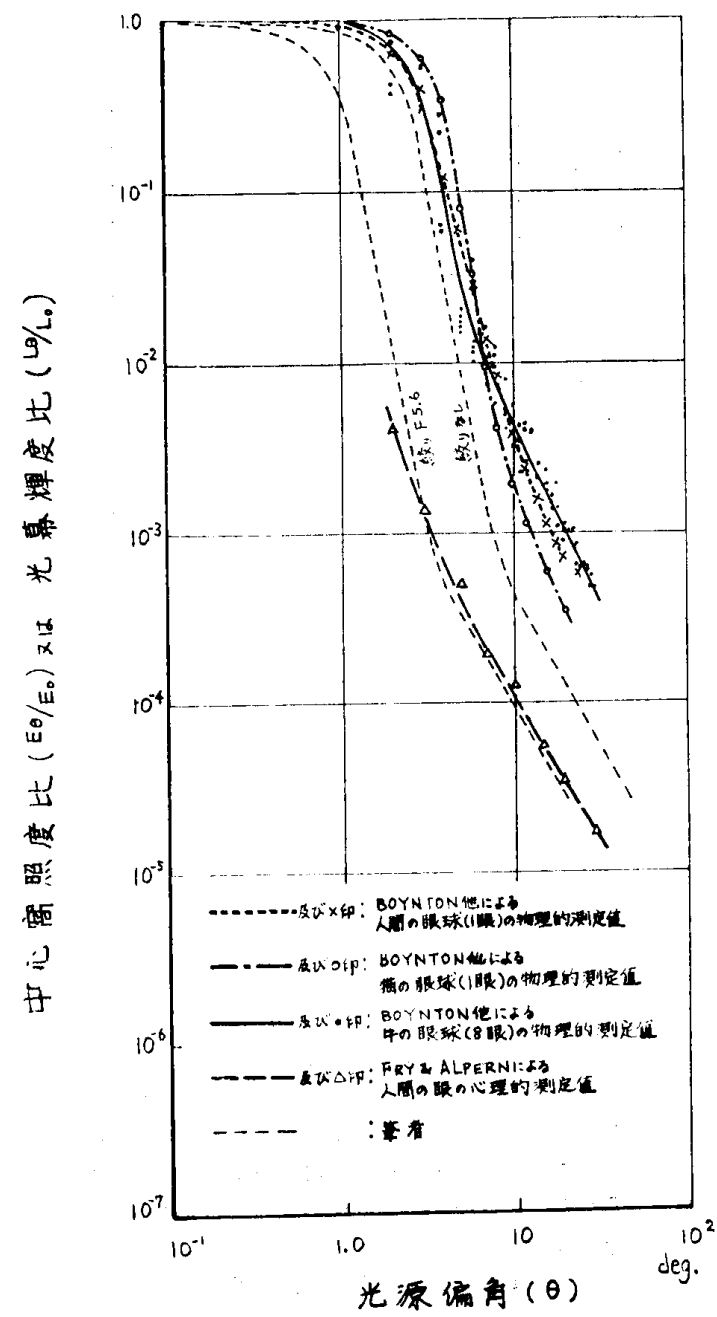

図一11眼球迷走光に関少る従来の研究結果 
大きいため光源からの直接光が光源偏角の大きな所まで 受光素子に入るからである。人間の注視点の大きさが約 $1^{\circ}$ であることからいって，照明設計のための基礎デー 夕を得る目的として BOYNTON の装置は適当でない。 しかも BOYNTON は光源の大きさによる影響をその 光源の立体角でもって補正して他の研究者の結果と比較 しているが，光源によって生じる中心窝への眼球迷走光 量が 光源偏角によって著しく変わると BOYNTON 自 身が述べているのに立体角だけで補正しているのは不充 分である。

FRY らの実験は人間の両眼比較による心理的実験で ある。FRY らの光幕輝度比は筆者の絞り F 5.6 の測定 結果に近い。しかし，明るさによって瞳孔径が変化する ことを考慮して比較すると, FRY の実験における光源 の輝度, 背景輝度, 瞳孔径が 不明のため断定出来ない が，いずれの光源偏角に於ても FRY らの光幕輝度比は 筆者の結果より小さい。この原因の一つとしては, 順応 のずれが考えられる。即ち FRY らの実験は両眼比較法 で行なわれており, 左右の眼の順応が独立して行なわ れ，また明るさの知覚 む左右の眼について完全に独立 して行なえたかどらか，はなはだ疑問がある。しかし STILES らの「人間の眼の 錐状体細胞には角特性があ り，このため心理的測定では実際に存在している迷走光 を過小評価してしまう」 ${ }^{12)}$ といら説には一致する。

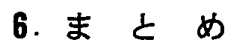

以上の結果をまとめると以下のようになる。

1） 眼球摘出後の経過時間が眼球走光量に与える影響 は, 眼球を $0^{\circ} \mathrm{C}$ の生理的食塩水中に 保存しておいた場 合, 10 時間以内, 特に 5 時間以内では無視出来る程度 である。(図一2 図一 4 )

2) 眼球迷走光量は光源偏角 $\left(\theta^{\circ}\right)$ によってかなり異 なり，視線近く（視線より $10^{\circ}$ 以内）に光源があるとき に著しい。(図一5)

3）眼球迷走光の原因としては，光源が視線から $10^{\circ}$ 以内の場合は, 眼球光学系の歪, 視線から $10^{\circ}$ 以上偏。 ている場合は，眼球の角膜表面での散乱が主であると考 察された。

4）人工絞りによって虹彩が絞られて瞳孔径が小さく なった状態を造った場合, 眼の光学系で最も歪の多い周 辺部を透過した光が遮断されているため, 眼球迷走光は 著しく減少する。(図一6, 図一9)

5）光源の大きさが眼球迷走光に与える影響は, 光源 を視角 $1^{\circ}$ の大きさに細分化し, その各部分に視角 $1^{\circ}$ の 光源で得た眼球迷走光量をあてはめて加算すると実測值
とほぼ一致することから, 光源の各部分によって起こる 眼球迷走光を総合することによって求められる。(表一4)

6）光源偏角と牛の眼球の中心窩照度比との関係を求 める実験式として次式が得られた。

$$
\begin{aligned}
& \theta>1^{\circ} \text { のとき, } \\
& \quad E_{\theta} / E_{0}=\exp \left\{(-\ln \theta)^{3}-0.25\right\}+0.032 \theta^{-1.8} \\
& \theta \leqq 1^{\circ} \text { のとき, } \\
& \quad E_{\theta} / E_{0}=\exp (-0.17 \theta) \\
& \text { この実験式值は, 実測值とよく一致する。(図一10) }
\end{aligned}
$$

稿を終るに当り，牛の眼球を提供してくださった大阪 市食肉市場の関保者の皆稴に心から感謝致します。また 本研究を進めるに際し, 御指導・御援助戴いた大阪大学 工学部教授 伊藤克三博士, 有役な御助言を戴いた大阪 市立大学生活科学部教授 大志野章博士, 医学部教授 松山道郎博士, 大手前病院眼科 山地良一博士, 建築学 会近畿支部環境工学委員会光分科会の諸先生方に深甚な る謝意を表します。更に種々御援助戴いた大阪市立大学 生活科学部住居機構研究室の諸先生方に心から感謝致し ます。

\section{文嶰}

1) 伊藤・中根他：等視力曲線に関する実験 (1) - (2), 建築 学会近戴支部研究報告集, 昭和 42 年 4 月

伊藤・中根他：明視照明のための基礎実験，建築学会論 文報告集, 号外, 昭和 42 年 10 月

伊藤・中根 : 不均一な背景輝度が 見易さに及ぼす影響に つWて (1)，建築学会学術溝演梗概集，炤和 44 年 8 月 伊藤・中根：不均一な背景輝度が 見易さに及ぼす影響に ついて (2), 建築学会学術講演梗概集, 昭和 46 年 11 月 中根・伊藤：明視照明のための 標準等視力曲線に関する 研究, 建築学会論文報告集, Vol. 229, 昭和 50 年 3 月 中根芳一：印刷文字の見易さ及び適正照度に関する研究， 建築学会論文報告集, Vol. 229, 昭和 50 年 3 月

2) 蒲山久夫活か：明視照明のための 基礎的研究, 照明学会 誌 46 (1962) 92

3) 中泉正德 : 日眼, 30 (1926) 701

4) C. Roggenban \& A. Wetthauer : Z.F. Augenh, 64 (1928) 143.

5) Ludvigh \& McCarshy : Arch. o. Oph. 20 (1938) 37.

6) Goldman H. etc. : Ophthalmologica, 120 (1950) 198.

7）山地良一：眼臨， 44 (1950) $415,569$.

8) 飯沼 撖：臨眼, 7 (1953) 819.

9）山地良一, 山本 担: 日眼, 58 (1954) $82,275,279$.

10) R.M. Boynton ... : Physical Measures of stray Light in Excised Eyes, J. Opt. Soc., America, Vol. 44, $1954,11$.

11) 同上 (10)

G.A. Fry … : J. Opt. Soc., America, Vol. 43, 1953, 3.

12) W.S. Stiles \& B.H. Crawford : Proc. Roy. Soc. 112, 1933, 428. 123, 1937, 90. 


\title{
SYNOPSIS
}

U.D.C. 628.9 .02

\section{PHYSICAL MEASURES OF STRAY LIGHT IN STEER'S EXCISED EYEBALLS}

\author{
by YOSHIKAZU NAKANE, Lect. of Osaka City Univ. and \\ TADASHI DOI, Graduate Student of Osaka City Univ., \\ Members of A.I.J.
}

By using steer's eyes, which are similar in optical characteristics to human eyes, we have measured the stray light in them. (See Table 1).

The results are summarized as follows :

1. The effect of time lapse after the excising of steer's eyeballs is negligible at least up to 10 hours. (See Figs. 2 4)

2. The quantity of stray lights increases as the light source approaches a point on the visual line, especially when the light source is within $10^{\circ}$ from the visual point. (See Fig. 5)

3. The causes of stray light are: (1) optical defects of eyes when the light source is within $10^{\circ}$ of the visual point; (2) diffusion of light on the surface of the cornea at angles greater than $10^{\circ}$.

4. The smaller the iris aperture, the smaller the quantity of stray lights. (See Figs. 6 and 9)

5. When a large light source is divided into $1^{\circ}$ units, the total sum of the stray light from each unit is almost equal to the quantity of the original light source. (See Table 4)

6. In order to obtain the ratio of $E_{\theta} / E_{0}$, the following equations are used :

$\theta>1^{\circ} \quad E_{\theta} / E_{0}=\exp \left\{(-\ln \theta)^{8}-0.25\right\}+0.032 \theta^{-1.8}$

$\theta \leqq 1^{\circ} \quad E_{\theta} / E_{0}=\exp (-0.17 \theta)$

where, $E_{0}$ : Illuminance of fovea when the light source is on the visual line $\left(\theta=0^{\circ}\right)$

$E_{\theta}$ : Illuminance of fovea when the light source deviates $\theta^{\circ}$ from the visual line. 